\title{
Effects of quinoa flour on lipid and protein oxidation in raw and cooked beef burger during long term frozen storage
}

\author{
Cem Okan ÖZER ${ }^{1 \star}$, Selçuk Mustafa SEÇEN ${ }^{1}$
}

\begin{abstract}
The objective of this work was to assess the effects of quinoa flour in the improving the quality characteristics and oxidation and storage stability $\left(-18^{\circ} \mathrm{C}\right.$ for 3 months) of cooked and raw beef burger. The effects of quinoa flour addition $(3,5,7$ and $10 \%)$ on physicochemical composition, $\mathrm{pH}$, cooking parameters and dimensional changes, color and texture characteristics of raw and cooked burgers were evaluated. Furthermore, lipid and protein oxidation stability for raw and cooked burgers were determined during long-term frozen storage. The cooking yield and reduction in diameter and thickness of burgers were improved and ash and protein contents of burger increased by the addition of quinoa. The control samples had the highest $\mathrm{pH}$. Texture analysis showed that with the addition of quinoa, hardness values of burger increased and adhesiveness values decreased. All groups showed similar $\mathrm{L}^{*}, \mathrm{a}^{*}$ and $\mathrm{b}^{*}$ values. The results indicated that addition of quinoa significantly decreased TBARS values for raw and cooked burger compared to control group during storage. However, the addition of quinoa flour did not affect protein oxidation level of raw and cooked burger.
\end{abstract}

Keywords: beef burger; quinoa; lipid oxidation; protein oxidation; quality parameters.

Practical Application: The use of quinoa flour in burger production may provide to improve quality characteristics.

\section{Introduction}

Consumers often avoid consuming meat and meat products due to health concerns caused by animal fat, saturated fatty acids, cholesterol, sodium nitrite and sodium chloride in meat products (Decker \& Park, 2010). However, food and nutritional scientists and some leading health organizations have also suggested that decreasing harmful components in meat products to human health and food and nutritional scientists and some leading health organizations have also suggested that decreasing harmful components in meat products to human health and improved meat products compositions with incorporated health enhancing ingredients (Lachance \& Fisher, 2005). Enrichment of meat products with some vegetable source compounds such as some cereals and fruits have been considered as a good strategy to development of functional meat products and studied extensively in recent years. The quinoa, which is shown as one of the most valuable of these vegetable sources, has also begun to be tried in the formulations of different products in many studies and their results have shown that quinoa can be very important ingredient for improving food quality and nutritional value (Arihara, 2006; Wang \& Zhu, 2016; Zhang et al., 2010).

Quinoa (Chenopodium quinoa Willd.) is a seed crop, which has some healthy properties such as easy to digest and a good sources of protein, dietary fiber, minerals and essential amino acids e.g. lysine, methionine and histidine (Ramos Diaz et al., 2015; Ibrahium, 2015). Additionally, the quinoa seed contains antioxidant compounds such as carotenoids and flavonoids (Dini et al., 2010; Maradini et al., 2017). Because of these important features, the enrichment of food products with quinoa became the interest of food industry to development of functional foods. Some studies have indicated that quinoa may be used as a diet supplement and binder because of its carbohydrate, fiber and protein content (Ramos Diaz et al., 2015, 2016). Although there are many studies about using quinoa and quinoa flour in different food manufacturing technologies such as bread, baby foods, flakes and beer, studies about using quinoa and quinoa flour in meat and meat products technology are limited in the literature(James, 2009; Maradini et al., 2017; Wang \& Zhu, 2016).

The main objective of this research was to evaluate the efficiency of added quinoa flour for inhibiting the development of lipid and protein oxidation further during freeze storage in cooked and raw beef hamburger. Furthermore, it was investigated the effect of quinoa flour on the quality parameters such as cooking parameters, $\mathrm{pH}$, color, moisture, protein, fat, ash, texture and in hamburger patties.

\section{Materials and methods}

\subsection{Beef burger preparation}

$24 \mathrm{~h}$ post-mortem boneless beef cuts (M. longissimus dorsi), beef back fat and other ingredients were purchased from a butcher shop (Nevşehir, Turkey). All subcutaneous fat and intermuscular fat was removed from the muscles and were ground through a $4 \mathrm{~mm}$ plate grinder. Whole grain quinoa were purchased from local food stores (Nevşehir, Turkey) and quinoa was milled to fine flour using 
a grinding device (Yücebaş Machinery, Izmir, Turkey). The burger contained $70 \%$ lean meat and $15 \%$ fat. Other ingredients added were as follows: $2 \% \mathrm{NaCl}, 4 \%$ grated onion, $1 \%$ grated garlic, $7 \%$ breadcrumbs, $0.5 \%$ black pepper and $0.5 \%$ cumin. Control groups were produced as in the above-described formulation, and other treatments were produced without breadcrumbs and with 3, 5, 7 and $10 \%$ quinoa flour, respectively. Hamburger dough was randomly divided into five treatment groups ( $2 \mathrm{~kg}$ each) and processed into burger that has $1 \mathrm{~cm}$ thickness, $90 \mathrm{~mm}$ diameter and $50 \mathrm{~g}$ weight by using a metal shaper. $1 \mathrm{~kg}$ of each batch burger was stored $-18^{\circ} \mathrm{C}$ for 90 days in vacuum-packages and other $1 \mathrm{~kg}$ of each batch burger was cooked using an electric plate. Cooking time was 3 min per side of the burgers and the core temperature was $70 \pm 2{ }^{\circ} \mathrm{C}$ at the end of the cooking time. The cooked burger was also stored $-18^{\circ} \mathrm{C}$ for 90 days in vacuum-packages. The entire experiment was replicated three times on separate processing days.

\subsection{Physicochemical composition}

Fat, protein, ash, moisture content and $\mathrm{pH}$ of all burgers were measured using Association of Official Analytical Chemists (2000) procedure. The $\mathrm{pH}$ was determined using $\mathrm{pH}$ meter (HI 9024, Hanna Instruments, Germany). pH meter was calibrated against 4 and $7 \mathrm{pH}$ buffer standards.

\subsection{Cooking measurements}

Cooking measurements were done on three replicates per treatment. Cooking yield, fat and moisture retention, reduction in diameter and thickness and shrinkage in diameter of burger was determined in cooked burgers (El-Magoli et al., 1996; Modi et al., 2004; Murphy et al., 1975).

\subsection{Lipid oxidation measurement}

The formations of thiobarbituric acid reactive substances (TBARS) were determined for evaluation of lipid oxidation stability. TBARS values of samples were determined as described by Kilic \& Richards (2003) at the manufacturing day and during storage period $(7,15,30,60,90 \mathrm{~d})$ for raw and cooked burgers. This method requires addition of EDTA and propyl gallate to the trichloroacetic acid (TCA) extraction solution to prevent the development of TBARS during the analytical procedure. Briefly, $1 \mathrm{~g}$ burger sample was weighted and blended into $6 \mathrm{~mL}$ of extraction solution (EDTA, propyl gallate and trichloroacetic acid). The sample was homogenized for $15 \mathrm{~s}$. The homogenate was filtered through filter paper (Whatman No: 1). Then, $1 \mathrm{~mL}$ filtrate was mixed with $1 \mathrm{~mL}$ of thiobarbituric acid (TBA) and vortexed. The mixture was heated at $100^{\circ} \mathrm{C}$ for $40 \mathrm{~min}$. After cooling, the sample was centrifuged at $2000 \mathrm{xg}$ for $5 \mathrm{~min}$. Absorbance was determined at $532 \mathrm{~nm}$ against a blank containing $1 \mathrm{~mL}$ TCA extraction solution and $1 \mathrm{~mL}$ TBA solution. The TBARS values were expressed as $\mu \mathrm{mol}$ TBARS per kg meat.

\subsection{Protein oxidation measurement}

The total carbonyl content were determined for evaluation of protein oxidation stability and as described by Laudadio \& Tufarelli (2011) at the manufacturing day and during storage period $(7,15,30,60,90 \mathrm{~d})$ for raw and cooked burgers. Briefly,
$1 \mathrm{~g}$ burger sample was homogenized in $20 \mathrm{mM}$ sodium phosphate buffer containing $6 \mathrm{M} \mathrm{NaCl}(\mathrm{pH} 6.5)$ for $1 \mathrm{~min}$. Then, $0.2 \mathrm{~mL}$ were taken from the homogenates and proteins were precipitated by cold $1 \mathrm{~mL}$ TCA (10\%) with centrifugation process for $5 \mathrm{~min}$ at $4200 \mathrm{~g}$. One pellet was treated with $1 \mathrm{~mL} 2 \mathrm{M} \mathrm{HCl}$ for measurement of protein concentration and the other with an equal volume of $0.2 \%(\mathrm{w} / \mathrm{v})$ dinitrophenylhydrazine in $2 \mathrm{M}$ $\mathrm{HCl}$ for measurement of carbonyl concentration. Samples were incubated for $1 \mathrm{~h}$ at room temperature $\left(22-24^{\circ} \mathrm{C}\right)$. Then, samples were precipitated by $1 \mathrm{~mL}$ TCA $(10 \%)$ and washed three times with $1 \mathrm{~mL}$ ethanol: ethyl acetate $(1: 1, \mathrm{v} / \mathrm{v})$ to remove excess dinitrophenylhydrazine. The pellets were dissolved in $1.5 \mathrm{~mL}$ of $20 \mathrm{mM}$ sodium phosphate buffer containing $6 \mathrm{M}$ guanidine $\mathrm{HCl}$ ( $\mathrm{pH}$ 6.5), stirred and centrifuged for $2 \mathrm{~min}$ at $4,200 \mathrm{~g}$. Protein concentration was calculated from the absorption at $280 \mathrm{~nm}$ using bovine serum albumin as the standard. The amount of carbonyls was expressed as nmol of carbonyl per mg of protein using an absorption coefficient of $21.0 \mathrm{nM}^{-1} \mathrm{~cm}^{-1}$ at $370 \mathrm{~nm}$ for protein hydrazones.

\subsection{Color measurement}

Color measurement was conducted by a Hunterlab model Precise Color Reader TCR 200 (BAMR Ltd., Claremont, South Africa) colorimeter using D65 as a standard daylight illuminant and a standard observer position of $10^{\circ} .8$ - $\mathrm{mm}$-diameter circle and the specular component included (SCI) mode was used to measure. The colorimeter was standardized against a white calibration plate $\left(D 65, L^{*}=97.79, a^{*}=-0.11, b^{*}=2.69\right)$. Three readings were taken and averaged for each of the three replications. Color values were determined at the manufacturing day and during storage period $(7,15,30,60,90 \mathrm{~d})$ for raw and cooked burgers.

\subsection{Texture profile analysis}

Texture profile analysis (TPA) tests were performed on cooked samples at $4 \pm 1{ }^{\circ} \mathrm{C}$ using a texture analyzer (Brookfield, CT3, Middleboro, MA, United States) to determine hardness $(\mathrm{N})$, adhesiveness (Ns), springiness, cohesiveness, and resilience. Samples were cut into $(1 \times 1 \times 1 \mathrm{~cm})$ from cooked burger and then held for equilibration to room temperature $\left(20^{\circ} \mathrm{C}\right)$, wrapped with plastic film for TPA. Test conditions were: probe (aluminum rectangular probe; $5 \mathrm{~cm} \times 4 \mathrm{~cm}$ ); test speed $5 \mathrm{~mm} / \mathrm{s}$; pre-test speed $2 \mathrm{~mm} / \mathrm{s}$, post-test speed $2 \mathrm{~mm} / \mathrm{s}$; compression $70 \%$ and $50 \mathrm{~kg}$ load cell. Three replicate measurements were taken for each sample per treatment and TPA parameters were determined as described by Bourne (1978).

\subsection{Statistical analysis}

The results were expressed as mean values with standard errors from the three replications. The statistical evaluation of the results was performed using the SPSS 22.0.0 (SPSS Inc., Chicago, USA). Data collected for chemical composition and physicochemical properties of burgers were analyzed by one-way analysis of variance (ANOVA). A completely randomized design was used with 5 treatment groups and 3 replications. The treatments were one control group and four groups, which were assigned, and the data were analyzed using general linear model (GLM) 
procedure, in which treatment groups and storage time were assigned as fixed effects and replications as a random effect. Duncan multiple comparison test was used to compare mean values and differences among mean values were considered significant when $P<0.05$.

\section{Results and discussion}

\subsection{Physicochemical composition analysis}

Physicochemical properties of used quinoa flour were determined and results showed that it contained $57.23 \% \pm 0.4$ carbohydrates, $14.94 \% \pm 0.2$ protein, $8.32 \% \pm 0.2$ fat, $3.12 \% \pm 0.1$ ash and $10.29 \% \pm 0.1$ dietary fiber. Additionally, $\mathrm{pH}$ of an aqueous dispersion of quinoa flour was $5.72 \pm 0.1$. The determined mean proximate compositions for quinoa are consistent with the literature (James, 2009; Kozioł, 1992; Ruales \& Nair, 1993).

The physicochemical compositions of raw and cooked beef burger formulated with different levels of quinoa flour are given in Table 1.

The use of quinoa flour had shown significant differences in protein and ash content for raw burger and protein and fat content for cooked burger $(P<0.05)$. The protein content for both raw and cooked burger was lower in control groups than other treatment groups $(P<0.05)$. Also, the highest fat content for cooked burger and lowest ash content for raw burger was determined in burger with $7 \%$ and $10 \%$ quinoa flour $(P<0.05)$. The effects of added quinoa flour on fat content may be related with the oil holding function of quinoa flour that leading to more oil retention in meat products during cooking process. Previous studies also support this idea and have reported that an increase in protein and ash content in produced meat products with vegetable ingredients was observed as the level of replacement with vegetable ingredients increased ( $\mathrm{Hu} \& \mathrm{Yu}, 2015$; Liu et al., 2015; Talukder, 2015).

The $\mathrm{pH}$ values of raw and cooked burger samples were observed during 90d storage (data is not presented). $\mathrm{pH}$ values ranged from 5.72 to 5.68 for raw burger and ranged from 5.83 to 5.98 for cooked burger on the manufacturing day. Results of $\mathrm{pH}$ analysis showed that quinoa flour had a non-significant effect on $\mathrm{pH}$ of the raw burger during manufacturing and storage period. However, significant differences in $\mathrm{pH}$ for cooked burgers were determined at the manufacturing and storage periods $(P<0.05)$. The $\mathrm{pH}$ values of cooked burger samples decreased depending on the amount of added quinoa flour in the burger formulation and control group had highest $\mathrm{pH}$ level among the other treatment groups at the manufacturing day $(P<0.05)$. The reason of decrease in $\mathrm{pH}$ of cooked burger may be related to fat and moisture retention ability of quinoa and $\mathrm{pH}$ of quinoa ( $\mathrm{pH}$ 5.72). Some researchers have reported that the change in $\mathrm{pH}$ on addition of vegetable source largely depends upon the $\mathrm{pH}$ of the added source and generally, plant-derived components, which had acidic $\mathrm{pH}$, when incorporated in meat products reduced $\mathrm{pH}$ of products as the level of incorporation increased. (Aleson-Carbonell et al., 2004; Dzudie et al., 2002; Grigelmo-Miguel et al., 1999). During the storage period, $\mathrm{pH}$ of beef burger samples insignificantly decreased and were shown a similar trend in both raw and cooked samples.

\subsection{Cooking measurements analysis}

Cooking characteristics of burgers are given in Table 2. The use of quinoa flour in burger showed a significant effect on all cooking properties values $(P<0.05)$. Cooking yield varied between $58.65 \%$ and $84.27 \%$ and the highest yield was found in samples with $10 \%$ quinoa flour. Similarly, highest fat and moisture retention value also were found in burger with $10 \%$ quinoa flour $(P<0.05)$. When increasing the amount of quinoa flour from $3 \%$ to $10 \%$, cooking yield, moisture and fat retention of burger significantly increased $(P<0.05)$. Generally, it can be said that the use of 3 and $5 \%$ quinoa flour and control group that contain $7 \%$ breadcrumbs in burger, had similar cooking characteristics. Additionally, quinoa flour significantly improved the reduction in diameter and thickness and shrinkage of burger $(P<0.05)$.

The lowest shrinkage values and reduction in diameter and thickness were determined in burger with $10 \%$ quinoa flour $(P<0.05)$. This improvement on cooking parameters could be related with functional properties of quinoa flour.

Table 1. Physicochemical composition* of raw and cooked beef burger.

\begin{tabular}{|c|c|c|c|c|c|}
\hline & Quinoa level (\%) & $\begin{array}{c}\text { Protein } \\
(\%)\end{array}$ & $\begin{array}{l}\text { Fat } \\
(\%)\end{array}$ & $\begin{array}{c}\text { Moisture } \\
(\%)\end{array}$ & Ash (\%) \\
\hline \multirow[t]{6}{*}{ Raw Beef Burger } & 0 & $23.34^{c}$ & $15.79^{\mathrm{a}}$ & $56.98^{\mathrm{a}}$ & $3.89^{\mathrm{b}}$ \\
\hline & 3 & $24.06^{\mathrm{b}}$ & $15.92^{\mathrm{a}}$ & $56.03^{\mathrm{a}}$ & $4.02^{\mathrm{b}}$ \\
\hline & 5 & $24.34^{\mathrm{ab}}$ & $15.82^{\mathrm{a}}$ & $55.75^{\mathrm{ab}}$ & $4.10^{\mathrm{b}}$ \\
\hline & 7 & $24.42^{\mathrm{ab}}$ & $15.81^{\mathrm{a}}$ & $55.32^{\mathrm{ab}}$ & $4.45^{\mathrm{a}}$ \\
\hline & 10 & $24.89^{\mathrm{a}}$ & $15.78^{\mathrm{a}}$ & $54.76^{\mathrm{b}}$ & $4.58^{\mathrm{a}}$ \\
\hline & SEM & 0.05 & 0.09 & 0.11 & 0.04 \\
\hline \multirow[t]{6}{*}{ Cooked Beef Burger } & 0 & $27.25^{\mathrm{c}}$ & $20.83^{\mathrm{b}}$ & $47.12^{\mathrm{a}}$ & $4.71^{\mathrm{a}}$ \\
\hline & 3 & $27.72^{\mathrm{b}}$ & $20.57^{c}$ & $47.19^{\mathrm{a}}$ & $4.62^{\mathrm{ab}}$ \\
\hline & 5 & $27.88^{\mathrm{ab}}$ & $20.81^{b c}$ & $46.86^{\mathrm{ab}}$ & $4.53^{\mathrm{ab}}$ \\
\hline & 7 & $28.01^{\mathrm{a}}$ & $21.63^{\mathrm{a}}$ & $46.06^{\mathrm{b}}$ & $4.34^{\mathrm{ab}}$ \\
\hline & 10 & $28.08^{\mathrm{a}}$ & $22.06^{\mathrm{a}}$ & $45.61^{\mathrm{b}}$ & $4.25^{\mathrm{b}}$ \\
\hline & SEM & 0.05 & 0.05 & 0.06 & 0.03 \\
\hline
\end{tabular}

SEM $=$ standard error of the mean; $(n=45) ;{ }^{\mathrm{a}, \mathrm{b}}(\downarrow)$ Different letters within a column are significantly different $(\mathrm{P}<0.05) ;{ }^{\star}$ All values are the mean of three replicates. 
Many studies reported that quinoa flour has high water and oil holding capacity, emulsifying and foaming capacity, gelation properties (Abugoch et al., 2008; James, 2009; Lindeboom, 2005; Ogungbenle et al., 2009). Dietary fiber, starch and protein in quinoa flour increased cooking yield and decreased shrinkage of burger samples. These results agree with studies about meat products containing dietary fiber and some vegetable protein and bakery products containing quinoa flour (Ergezer et al., 2014; Park \& Morita, 2005; Rizzello et al., 2009).

\subsection{Lipid oxidation analysis}

The oxidative rancidity measured by TBARS values is presented in Table 3. The TBARS values for both raw and cooked burger gradually increased during storage period $(P<0.05)$. The use of quinoa flour in burger had shown no significant effect on TBARS values at the manufacturing day for both raw and cooked burger. However, TBARS values of raw burger with $5,7,10 \%$ quinoa flour had lower than other treatment groups during the first month of storage $(P<0.05)$ and control group had highest TBARS values at 60 and 90 days of storage $(P<0.05)$.
The antioxidant effect of quinoa flour has been identified in raw beef burger at all usage rates $(3,5,7,10 \%)$ during $-18^{\circ} \mathrm{C}$ storage for 90 days. Previous studies reported that quinoa has remarkable and higher antioxidant activity than some cereals because of its phenolic and flavonoid content and it can be used as a source of free radical scavenging agents (Gorinstein et al., 2008; James, 2009; Zhu et al., 2001). The use of quinoa flour in cooked burger had shown no significant effect on TBARS values during the first week of storage, unlike the raw burger. After the $7 \mathrm{~d}$ of storage, group with $5 \%$ quinoa flour had lowest TBARS values in the rest of storage period $(P<0.05)$. TBARS values during the storage period were found to be at the same level for control, $7 \%$ and $10 \%$ quinoa flour group. This situation may be associated with moisture and oil retention function of quinoa flour. Both $7 \%$ and $10 \%$ quinoa flour groups had higher fat and moisture binding than other treatments during the cooking process, and so fat and moisture content that are important components for oxidative stability are higher than other groups. Therefore, degrees of oxidative rancidity for $7 \%$ and $10 \%$ quinoa flour group were at the same level for control.

Table 2. Cooking parameters ${ }^{\star}$ of beef burger formulated with different levels of quinoa flour.

\begin{tabular}{|c|c|c|c|c|c|c|}
\hline Quinoa level (\%) & Cooking yield (\%) & Fat retention (\%) & $\begin{array}{c}\text { Moisture retention } \\
(\%)\end{array}$ & $\begin{array}{l}\text { Reduction in } \\
\text { diameter (\%) }\end{array}$ & $\begin{array}{l}\text { Reduction in } \\
\text { thickness (\%) }\end{array}$ & Shrinkage (\%) \\
\hline 0 & $58.65^{\mathrm{e}}$ & $16.36^{\mathrm{d}}$ & $21.35^{\mathrm{b}}$ & $16.45^{\mathrm{ab}}$ & $26.60^{\mathrm{b}}$ & $-30.67^{a}$ \\
\hline 3 & $63.49^{\mathrm{d}}$ & $12.15^{\mathrm{e}}$ & $17.73^{\mathrm{d}}$ & $17.52^{\mathrm{a}}$ & $33.28^{\mathrm{a}}$ & $-44.67^{\mathrm{b}}$ \\
\hline 7 & $80.78^{b}$ & $23.28^{\mathrm{b}}$ & $24.83^{\mathrm{a}}$ & $7.17^{\mathrm{c}}$ & $21.99^{c}$ & $-58.67^{c}$ \\
\hline 10 & $84.27^{\mathrm{a}}$ & $28.66^{\mathrm{a}}$ & $26.51^{\mathrm{a}}$ & $4.10^{\mathrm{d}}$ & $20.10^{c}$ & $-63.33^{c}$ \\
\hline
\end{tabular}

SEM $=$ standard error of the mean; $(n=45) ;{ }^{\text {a-e }}(\downarrow)$ Different letters within a column are significantly different $(\mathrm{P}<0.05) ;{ }^{\star}$ All values are the mean of three replicates.

Table 3. TBARS levels ${ }^{\star}$ of raw and cooked beef burger formulated with different levels of quinoa flour at manufacturing and storage period ( $\mu \mathrm{mol}$ TBARS / kg meat).

\begin{tabular}{|c|c|c|c|c|c|c|c|c|c|}
\hline & \multirow{2}{*}{ Quinoa level (\%) } & \multirow{2}{*}{ Manufacturing day } & \multicolumn{6}{|c|}{$-18^{\circ} \mathrm{C}$ Storage (days) } & \multirow{2}{*}{ SEM } \\
\hline & & & $1 \mathrm{~d}$ & $7 \mathrm{~d}$ & $15 \mathrm{~d}$ & $30 \mathrm{~d}$ & $60 \mathrm{~d}$ & $90 \mathrm{~d}$ & \\
\hline \multirow{4}{*}{$\begin{array}{l}\text { Raw } \\
\text { beef } \\
\text { burger }\end{array}$} & 0 & $1.80^{\mathrm{aG}}$ & $2.33^{\mathrm{aF}}$ & $2.67^{\mathrm{aE}}$ & $3.30^{\mathrm{aD}}$ & $5.07^{\mathrm{aC}}$ & $8.51^{\mathrm{aB}}$ & $11.49^{\mathrm{aA}}$ & 0.05 \\
\hline & 3 & $1.90^{\mathrm{aG}}$ & $2.29^{\mathrm{aF}}$ & $2.64^{\mathrm{aE}}$ & $3.27^{\mathrm{aD}}$ & $4.91^{\mathrm{aC}}$ & $7.92^{\mathrm{bB}}$ & $11.02^{\mathrm{bA}}$ & 0.08 \\
\hline & 7 & $1.90^{\mathrm{aG}}$ & $2.10^{\mathrm{bF}}$ & $2.43^{\mathrm{bE}}$ & $3.03^{\mathrm{bD}}$ & $4.56^{\mathrm{cC}}$ & $7.47^{\mathrm{dB}}$ & $9.76^{\mathrm{dA}}$ & 0.06 \\
\hline & 10 & $1.80^{\mathrm{aG}}$ & $2.03^{\mathrm{cF}}$ & $2.42^{\mathrm{bE}}$ & $3.00^{\mathrm{bD}}$ & $4.17^{\mathrm{dC}}$ & $6.82^{\mathrm{eB}}$ & $9.35^{\mathrm{eA}}$ & 0.08 \\
\hline \multirow{5}{*}{$\begin{array}{c}\text { Cooked } \\
\text { beef } \\
\text { burger }\end{array}$} & 3 & $2.35^{\mathrm{aG}}$ & $2.70^{\mathrm{bF}}$ & $3.21^{\mathrm{bE}}$ & $4.02^{\mathrm{bD}}$ & $6.06^{\mathrm{bC}}$ & $9.81^{\mathrm{bB}}$ & $13.00^{\mathrm{bA}}$ & 0.06 \\
\hline & 5 & $2.30^{\mathrm{aG}}$ & $2.51^{\mathrm{cF}}$ & $3.09^{\mathrm{cE}}$ & $3.60^{\mathrm{cD}}$ & $5.35^{\mathrm{dC}}$ & $8.59^{\mathrm{dB}}$ & $10.64^{\mathrm{dA}}$ & 0.05 \\
\hline & 7 & $2.31^{\mathrm{aG}}$ & $2.64^{\mathrm{bcF}}$ & $3.17^{\mathrm{bcE}}$ & $3.95^{\mathrm{bD}}$ & $5.79^{\mathrm{cC}}$ & $9.41^{\mathrm{cB}}$ & $12.29^{\mathrm{CA}}$ & 0.08 \\
\hline & 10 & $2.26^{\mathrm{aG}}$ & $2.76^{\mathrm{abF}}$ & $3.27^{\mathrm{abE}}$ & $4.12^{\mathrm{abD}}$ & $6.28^{\mathrm{aC}}$ & $10.23^{\mathrm{aB}}$ & $14.48^{\mathrm{aA}}$ & 0.05 \\
\hline & SEM & 0.03 & 0.02 & 0.06 & 0.03 & 0.05 & 0.13 & 0.05 & \\
\hline
\end{tabular}

SEM = standard error of the mean; $(\mathrm{n}=45){ }^{\mathrm{a}-\mathrm{e}}(\downarrow)$ Different letters within a column are significantly different $(\mathrm{P}<0.05)$; ${ }^{\mathrm{A}-\mathrm{G}}(\rightarrow)$ Different letters within a raw are significantly different $(\mathrm{P}<0.05)$;

${ }^{*}$ All values are the mean of three replicates. 


\subsection{Protein oxidation analysis}

No significant effect on protein oxidation was observed related to using quinoa flour in raw and cooked burger during frozen storage (Table 4).

Protein oxidation levels for both raw and cooked burger gradually increased during storage period $(P<0.05)$. Some researchers have reported that lipid and protein oxidation may be related in certain oxidizing systems and the timely interaction in several meat systems (Lund et al., 2011; Mercier et al., 1998). However, our results are different from this opinion. While the lipid oxidation level in using quinoa flour group had lower than control, there are no significant differences were determined for protein oxidation levels among all groups. These results may be related may be related to increasing protein and some essential amino acids content such as lysine, methionine and histidine which are abundant in quinoa and play important role in protein oxidation. Laudadio \& Tufarelli (2011) reported that the oxidative degradation occurs on side chains of lysine and histidine amino acids and forms carbonyl compounds. Therefore, the reason to obtained unlike results with lipid oxidation in protein oxidation results may be related with increasing the protein and some essential amino acids content such as lysine, methionine and histidine due to the quinoa addition.

\subsection{Color analysis}

Quinoa flour was shown a similar effect on color values $\left(L^{\star}, a^{\star}, b^{\star}\right)$ in raw and cooked burger (data is not presented). The use of quinoa flour in raw and cooked beef burger resulted in increased $L^{*}$ and $b^{*}$ values at a level of 7 and $10 \%(P<0.05)$ and decreased $\mathrm{a}^{\star}$ values at a level of $10 \%(P<0.05)$. During the storage period, pigment oxidation has taken place and redness values decreased (Jouki \& Khazaei, 2012). Our results were similar to some previous studies about the use of some flour in meat products and researchers have indicated that responsible of color differences in meat products used different flour has the dilution of meat pigments rather than the color of the flour additives (Alakali et al., 2010; Ergezer et al., 2014; Tabarestani \& Tehrani, 2014).

\subsection{Texture profile analysis}

The use of quinoa flour in cooked burger had shown a significant effect on all textural properties except resilience, cohesiveness and springiness index (Table 5).

Table 4. Carbonyl protein levels ${ }^{\star}$ of raw and cooked beef burger formulated with different levels of quinoa flour at manufacturing and storage period (nmol DNPH / mg protein)

\begin{tabular}{|c|c|c|c|c|c|c|c|c|c|}
\hline & \multirow{2}{*}{ Quinoa level (\%) } & \multirow{2}{*}{ Manufacturing day } & \multicolumn{6}{|c|}{$-18^{\circ} \mathrm{C}$ Storage (days) } & \multirow{2}{*}{ SEM } \\
\hline & & & $1 \mathrm{~d}$ & $7 \mathrm{~d}$ & $15 \mathrm{~d}$ & $30 \mathrm{~d}$ & $60 \mathrm{~d}$ & $90 \mathrm{~d}$ & \\
\hline \multirow[t]{6}{*}{ Raw beef burger } & 0 & $0.43^{\mathrm{aF}}$ & $0.43^{\mathrm{aF}}$ & $0.53^{\mathrm{aE}}$ & $0.67^{\mathrm{aD}}$ & $1.09^{\mathrm{aC}}$ & $1.25^{\mathrm{aB}}$ & $1.43^{\mathrm{aA}}$ & 0.04 \\
\hline & 3 & $0.41^{\mathrm{aF}}$ & $0.44^{\mathrm{aF}}$ & $0.54^{\mathrm{aE}}$ & $0.67^{\mathrm{aD}}$ & $1.11^{\mathrm{aC}}$ & $1.23^{\mathrm{aB}}$ & $1.46^{\mathrm{aA}}$ & 0.06 \\
\hline & 5 & $0.42^{\mathrm{aF}}$ & $0.44^{\mathrm{aF}}$ & $0.58^{\mathrm{aE}}$ & $0.69^{\mathrm{aD}}$ & $1.11^{\mathrm{aC}}$ & $1.21^{\mathrm{aB}}$ & $1.37^{\mathrm{bA}}$ & 0.04 \\
\hline & 7 & $0.44^{\mathrm{aF}}$ & $0.46^{\mathrm{aF}}$ & $0.53^{\mathrm{aE}}$ & $0.63^{\mathrm{abD}}$ & $1.14^{\mathrm{aC}}$ & $1.29^{\mathrm{aB}}$ & $1.44^{\mathrm{aA}}$ & 0.05 \\
\hline & 10 & $0.42^{\mathrm{aF}}$ & $0.46^{\mathrm{aF}}$ & $0.59^{\mathrm{aE}}$ & $0.61^{\mathrm{bD}}$ & $1.13^{\mathrm{aC}}$ & $1.24^{\mathrm{aB}}$ & $1.39^{\mathrm{abA}}$ & 0.03 \\
\hline & SEM & 0.09 & 0.07 & 0.12 & 0.04 & 0.05 & 0.14 & 0.06 & \\
\hline \multirow{6}{*}{$\begin{array}{c}\text { Cooked beef } \\
\text { burger }\end{array}$} & 0 & $0.62^{\mathrm{aF}}$ & $0.61^{\mathrm{aF}}$ & $0.71^{\mathrm{aE}}$ & $0.82^{\mathrm{bD}}$ & $1.18^{\mathrm{aC}}$ & $1.56^{\mathrm{bB}}$ & $1.86^{\mathrm{abA}}$ & 0.06 \\
\hline & 3 & $0.60^{\mathrm{aF}}$ & $0.62^{\mathrm{aF}}$ & $0.71^{\mathrm{aE}}$ & $0.84^{\mathrm{abD}}$ & $1.20^{\mathrm{aC}}$ & $1.56^{\mathrm{bB}}$ & $1.91^{\mathrm{aA}}$ & 0.11 \\
\hline & 5 & $0.58^{\mathrm{aF}}$ & $0.61^{\mathrm{aF}}$ & $0.72^{\mathrm{aE}}$ & $0.83^{\mathrm{bD}}$ & $1.24^{\mathrm{aC}}$ & $1.60^{\mathrm{abB}}$ & $1.93^{\mathrm{aA}}$ & 0.08 \\
\hline & 7 & $0.61^{\mathrm{aF}}$ & $0.62^{\mathrm{aF}}$ & $0.75^{\mathrm{aE}}$ & $0.85^{\mathrm{abD}}$ & $1.23^{\mathrm{aC}}$ & $1.64^{\mathrm{aB}}$ & $1.87^{\mathrm{abA}}$ & 0.04 \\
\hline & 10 & $0.59^{\mathrm{aF}}$ & $0.61^{\mathrm{aF}}$ & $0.77^{\mathrm{aE}}$ & $0.88^{\mathrm{aD}}$ & $1.24^{\mathrm{aC}}$ & $1.69^{\mathrm{aB}}$ & $1.84^{\mathrm{bA}}$ & 0.07 \\
\hline & SEM & 0.11 & 0.08 & 0.07 & 0.16 & 0.10 & 0.09 & 0.08 & \\
\hline
\end{tabular}

SEM = standard error of the mean; $(\mathrm{n}=45)$; $^{\mathrm{a}-\mathrm{b}}(\downarrow)$ Different letters within a column are significantly different $(\mathrm{P}<0.05)$; ${ }^{\mathrm{A}-\mathrm{F}}(\rightarrow)$ Different letters within a row are significantly different $(\mathrm{P}<0.05) ;{ }^{\star}$ All values are the mean of three replicates.

Table 5. Texture profile analysis* of cooked beef burger.

\begin{tabular}{|c|c|c|c|c|c|c|c|}
\hline Quinoa level (\%) & Hardness $(\mathrm{N})$ & $\begin{array}{c}\text { Adhesiveness } \\
(\mathrm{mj})\end{array}$ & Resilience & Cohesiveness & $\begin{array}{c}\text { Springiness } \\
\text { Index }\end{array}$ & Gumminess $(\mathrm{N})$ & Chewiness Index \\
\hline 0 & $92.20^{c}$ & $-6.12^{\mathrm{b}}$ & $0.16^{\mathrm{bc}}$ & $0.38^{\mathrm{a}}$ & $0.61^{\mathrm{a}}$ & $88.12^{b}$ & $905.45^{\mathrm{b}}$ \\
\hline 3 & $97.61^{a}$ & $-5.64^{c}$ & $0.13^{c}$ & $0.36^{\mathrm{a}}$ & $0.56^{\mathrm{a}}$ & $109.60^{\mathrm{a}}$ & $1006.12^{\mathrm{a}}$ \\
\hline 5 & $88.72^{\mathrm{b}}$ & $-6.04^{\mathrm{b}}$ & $0.21^{\mathrm{a}}$ & $0.35^{\mathrm{a}}$ & $0.64^{\mathrm{a}}$ & $94.65^{\mathrm{b}}$ & $864.24^{c}$ \\
\hline 7 & $80.67^{c}$ & $-6.65^{b}$ & $0.27^{\mathrm{ab}}$ & $0.31^{\mathrm{a}}$ & $0.63^{\mathrm{a}}$ & $90.12^{\mathrm{b}}$ & $760.68^{d}$ \\
\hline \multirow[t]{2}{*}{10} & $72.11^{\mathrm{d}}$ & $-10.06^{\mathrm{a}}$ & $0.20^{\mathrm{b}}$ & $0.34^{\mathrm{a}}$ & $0.61^{\mathrm{a}}$ & $71.25^{c}$ & $641.27^{\mathrm{e}}$ \\
\hline & 0.12 & 0.21 & 0.06 & 0.65 & 0.11 & 0.15 & 0.18 \\
\hline
\end{tabular}

a-e $(\downarrow)$ Different letters within a column are significantly different $(\mathrm{p}<0.05) ;{ }^{\star}$ All values are the mean \pm standard error of three replicates. 
Burger with $10 \%$ quinoa flour had the lowest hardness, adhesiveness, gumminess and chewiness index values and however, burgers with the $3 \%$ quinoa flour had the highest values for these properties $(P<0.05)$. Responsible for these results may be hydrochemical and physical properties of components in quinoa flour. Some researchers reported that carbohydrates such as starch and dietary fiber component in the added vegetable sources may interact with water and fat of meat products to form a softer texture thus leading to a change in textural properties (Ergezer et al., 2014; Kurt \& Kilincceker, 2012). Similar results have been reported the use of some ingredients such as oatmeal, Nata, rice bran (Choi et al., 2011; Lin \& Lin, 2004; Yang et al., 2007).

\section{Conclusion}

Production of beef burger with the quinoa flour can be improved nutritional quality of burger without adversely affecting the quality characteristics. Ash and dietary fiber content of burger can be increased and protein and essential amino acids content can be enhanced by vegetable protein by using quinoa flour. Additionally, use of quinoa flour inhibited lipid oxidation during frozen storage for both raw and cooked burger.

\section{References}

Abugoch, L. E., Romero, N., Tapia, C. A., Silva, J., \& Rivera, M. (2008). Study of some physicochemical and functional properties of quinoa (Chenopodium quinoa willd) protein isolates. Journal of Agricultural and Food Chemistry, 56(12), 4745-4750. http://dx.doi.org/10.1021/ jf703689u. PMid:18489119.

Alakali, J., Irtwange, S., \& Mzer, M. (2010). Quality evaluation of beef patties formulated with bambara groundnut (Vigna subterranean L.) seed flour. Meat Science, 85(2), 215-223. http://dx.doi.org/10.1016/j. meatsci.2009.12.027. PMid:20374888.

Aleson-Carbonell, L., Fernandez-Lopez, J., Sendra, E., Sayas-Barbera, E., \& Perez-Alvarez, J. A. (2004). Quality characteristics of a nonfermented dry-cured sausage formulated with lemon albedo. Journal of the Science of Food and Agriculture, 84(15), 2077-2084. http:// dx.doi.org/10.1002/jsfa.1912.

Arihara, K. (2006). Strategies for designing novel functional meat products. Meat Science, 74(1), 219-229. http://dx.doi.org/10.1016/j. meatsci.2006.04.028. PMid:22062731.

Association of Official Analytical Chemists - AOAC. (2000). Official methods of analysis (17th ed). Washington: AOAC.

Bourne, M. C. (1978). Texture profile analysis. Food Technology, 32, 62-66.

Choi, Y. S., Choi, J. H., Han, D. J., Kim, H. Y., Lee, M. A., Kim, H. W., Jeong, J. Y., \& Kim, C. J. (2011). Effects of rice bran fiber on heatinduced gel prepared with pork salt-soluble meat proteins in model system. Meat Science, 88(1), 59-66. http://dx.doi.org/10.1016/j. meatsci.2010.12.003. PMid:21208751.

Decker, E. A., \& Park, Y. (2010). Healthier meat products as functional foods. Meat Science, 86(1), 49-55. http://dx.doi.org/10.1016/j. meatsci.2010.04.021. PMid:20580991.

Dini, I., Tenore, G. C., \& Dini, A. (2010). Antioxidant compound contents and antioxidant activity before and after cooking in sweet and bitter Chenopodium quinoa seeds. Lebensmittel-Wissenschaft + Technologie, 43(3), 447-451. http://dx.doi.org/10.1016/j.lwt.2009.09.010.
Dzudie, T., Scher, J., \& Hardy, J. (2002). Common bean flour as an extender in beef sausages. Journal of Food Engineering, 52(2), 143 147. http://dx.doi.org/10.1016/S0260-8774(01)00096-6.

El-Magoli, S. B., Laroia, S., \& Hansen, P. M. T. (1996). Flavor and texture characteristics of low fat ground beef patties formulated with whey protein concentrate. Meat Science, 42(2), 179-193. http://dx.doi. org/10.1016/0309-1740(95)00032-1. PMid:22060683.

Ergezer, H., Akcan, T., \& Serdaroglu, M. (2014). The effects of potato puree and bread crumbs on some quality characteristics of low fat meatballs. Han-gug Chugsan Sigpum Hag-hoeji, 34(5), 561-569. http://dx.doi.org/10.5851/kosfa.2014.34.5.561. PMid:26761488.

Gorinstein, S., Lojek, A., Milan, Pawelzik, E., Delgado-Licon, E., Medina, O. J., Moreno, M., Salas, I. A., \& Goshev, I. (2008). Comparison of composition and antioxidant capacity of some cereals and pseudocereals. International Journal of Food Science \& Technology, 43(4), 629-637. http://dx.doi.org/10.1111/j.1365-2621.2007.01498.x.

Grigelmo-Miguel, N., Abadías-Serós, M. I., \& Martín-Belloso, O. (1999). Characterisation of low-fat high-dietary fibre frankfurters. Meat Science, 52(3), 247-256. http://dx.doi.org/10.1016/S03091740(98)00173-9. PMid:22062572.

Hu, G., \& Yu, W. (2015). Effect of hemicellulose from rice bran on low fat meatballs chemical and functional properties. Food Chemistry, 186, 239-243. http://dx.doi.org/10.1016/j.foodchem.2014.07.063. PMid:25976816.

Ibrahium, M. I. (2015). Minerals bioavailability of wheat biscuit supplemented by quinoa flour. The Middle East Journal, 4(4), 769-778.

James, L. E. A. (2009). Quinoa (Chenopodium quinoa Willd.): composition, chemistry, nutritional, and functional properties. Advances in Food and Nutrition Research, 58, 1-31. http://dx.doi. org/10.1016/S1043-4526(09)58001-1. PMid:19878856.

Jouki, M., \& Khazaei, N. (2012). Color and oxidation changes in camel meat during storage. International Journal of Pharma and Bio Sciences, 3, 164-170.

Kilic, B., \& Richards, M. P. (2003). Lipid oxidation in poultry doner kebab: pro-oxidative and anti-oxidative factors. Journal of Food Science, 68(2), 686-689. http://dx.doi.org/10.1111/j.1365-2621.2003. tb05732.x.

Kozioł, M. (1992). Chemical composition and nutritional evaluation of quinoa (Chenopodium quinoa Willd.). Journal of Food Composition and Analysis, 5(1), 35-68. http://dx.doi.org/10.1016/0889-1575(92)90006-6.

Kurt, S., \& Kilincceker, O. (2012). The Effects of cereal and legume flours on the quality characteristics of beef patties. Kafkas Üniversitesi Veteriner Fakültesi Dergisi, 18(5), 725-730.

Lachance, P. A., \& Fisher, M. C. (2005). Reinvention of the food guide pyramid to promote health. Advances in Food and Nutrition Research, 49, 1-39. http://dx.doi.org/10.1016/S1043-4526(05)490014. PMid:15797342.

Laudadio, V., \& Tufarelli, V. (2011). Pea (Pisumsativum L.) seeds as an alternative dietary protein source for broilers: influence on fatty acid composition, lipid and protein oxidation of dark and white meats. Journal of the American Oil Chemists' Society, 88(7), 967-973. http:// dx.doi.org/10.1007/s11746-010-1742-3.

Lin, K. W., \& Lin, H. Y. (2004). Quality characteristics of Chinesestyle meatball containing bacterial cellulose (nata). Journal of Food Science, 69(3), S107-S111.

Lindeboom, N. (2005). Studies on the characterization, biosynthesis and isolation of starch and protein from quinoa (Chenopodium quinoa Willd.). Saskatoon: University of Saskatchewan.

Liu, R., Wang, N., Li, Q., \& Zhang, M. (2015). Comparative studies on physicochemical properties of raw and hydrolyzed oat $\beta$-glucan 
and their application in low-fat meatballs. Food Hydrocolloids, 51, 424-431. http://dx.doi.org/10.1016/j.foodhyd.2015.04.027.

Lund, M. N., Heinonen, M., Baron, C. P., \& Estevez, M. (2011). Protein oxidation in muscle foods: a review. Molecular Nutrition \& Food Research, 55(1), 83-95. http://dx.doi.org/10.1002/mnfr.201000453. PMid:21207515.

Maradini, A. M. Fo, Pirozi, M. R., Borges, J. T. D. S., Sant’Ana, H. M., Chaves, J. B. P., \& Coimbra, J. S. D. R. (2017). Quinoa: nutritional, functional and antinutritional aspects. Critical Reviews in Food Science and Nutrition, 57(8), 1618-1630. http://dx.doi.org/10.108 0/10408398.2014.1001811. PMid:26114306.

Mercier, Y., Gatellier, P., Viau, M., Remignon, H., \& Renerre, M. (1998). Effect of dietary fat and vitamin $\mathrm{E}$ on colour stability and on lipid and protein oxidation in turkey meat during storage. Meat Science, 48(3-4), 301-318. http://dx.doi.org/10.1016/S0309-1740(97)001137. PMid:22063078.

Modi, V. K., Mahendrakar, N. S., Narasimha Rao, D., \& Sachindra, N. M. (2004). Quality of buffalo meat burger containing legume flours as binders. Meat Science, 66(1), 143-149. http://dx.doi.org/10.1016/ S0309-1740(03)00078-0. PMid:22063942.

Murphy, E. W., Criner, P. E., \& Gray, B. C. (1975). Comparisons of methods for calculating retentions of nutrients in cooked foods. Journal of Agricultural and Food Chemistry, 23(6), 1153-1157. http:// dx.doi.org/10.1021/jf60202a021. PMid:1238446.

Ogungbenle, H., Oshodi, A., \& Oladimeji, M. (2009). The proximate and effect of salt applications on some functional properties of quinoa (Chenopodium quinoa) flour. Pakistan Journal of Nutrition, 8(1), 49-52. http://dx.doi.org/10.3923/pjn.2009.49.52.

Park, S. H., \& Morita, N. (2005). Dough and breadmaking properties of wheat flour substituted by $10 \%$ with germinated quinoa flour. Food Science \& Technology International, 11(6), 471-476. http:// dx.doi.org/10.1177/1082013205060766.

Ramos Diaz, J. M., Sundarrajan, L., Kariluoto, S., Lampi, A. M., Tenitz, S., \& Jouppila, K. (2016). Effect of extrusion cooking on physical properties and chemical composition of corn-based snacks containing amaranth and quinoa: application of partial least squares regression. Journal of Food Process Engineering. In press.
Ramos Diaz, J. M., Suuronen, J.-P., Deegan, K. C., Serimaa, R., Tuorila, H., \& Jouppila, K. (2015). Physical and sensory characteristics of corn-based extruded snacks containing amaranth, quinoa and kaniwa flour. Lebensmittel-Wissenschaft + Technologie, 64(2), 1047-1056. http://dx.doi.org/10.1016/j.lwt.2015.07.011.

Rizzello, C. G., Coda, R., De Angelis, M., Di Cagno, R., Carnevali, P., \& Gobbetti, M. (2009). Long-term fungal inhibitory activity of water-soluble extract from Amaranthus spp. seeds during storage of gluten-free and wheat flour breads. International Journal of Food Microbiology, 131(2-3), 189-196. http://dx.doi.org/10.1016/j. ijfoodmicro.2009.02.025. PMid:19328576.

Ruales, J., \& Nair, B. M. (1993). Content of fat, vitamins and minerals in quinoa (Chenopodium quinoa, Willd) seeds. Food Chemistry, 48(2), 131-136. http://dx.doi.org/10.1016/0308-8146(93)90047-J.

Tabarestani, H. S., \& Tehrani, M. M. (2014). Optimization of physicochemical properties of low-fat hamburger formulation using blend of soy flour, split-pea flour and wheat starch as part of fat replacer system. Journal of Food Processing and Preservation, 38(1), 278-288. http://dx.doi.org/10.1111/j.1745-4549.2012.00774.x.

Talukder, S. (2015). Effect of dietary fiber on properties and acceptance of meat products: a review. Critical Reviews in Food Science and Nutrition, 55(7), 1005-1011. http://dx.doi.org/10.1080/10408398. 2012.682230. PMid:24915339.

Wang, S. N., \& Zhu, F. (2016). Formulation and quality attributes of quinoa food products. Food and Bioprocess Technology, 9(1), 49-68. http://dx.doi.org/10.1007/s11947-015-1584-y.

Yang, H. S., Choi, S. G., Jeon, J. T., Park, G. B., \& Joo, S. T. (2007). Textural and sensory properties of low fat pork sausages with added hydrated oatmeal and tofu as texture-modifying agents. Meat Science, 75(2), 283-289. http://dx.doi.org/10.1016/j.meatsci.2006.07.013. PMid:22063660.

Zhang, W. A., Xiao, S., Samaraweera, H., Lee, E. J., \& Ahn, D. U. (2010). Improving functional value of meat products. Meat Science, 86(1), 1531. http://dx.doi.org/10.1016/j.meatsci.2010.04.018. PMid:20537806.

Zhu, N. Q., Sheng, S. Q., Li, D. J., Lavoie, E. J., Karwe, M. V., Rosen, R. T., \& Ho, C. T. (2001). Antioxidative flavonoid glycosides from quinoa seeds (Chenopodium quinoa Willd). Journal of Food Lipids, 8(1), 37-44. http://dx.doi.org/10.1111/j.1745-4522.2001.tb00182.x. 